\title{
Feed Resources Potential and Nutritional Quality of Major Feed Stuffs in Raya Kobo District, North Wollo Zone, Ethiopia
}

\author{
Derbie Alemu ${ }^{1}$, Ermias Tekletsadik ${ }^{2,}$,, Mekonnen Yirga ${ }^{3}$, Melaku Tareke $^{2}$ \\ ${ }^{1}$ Department of Animal Sciences, College of Agriculture and Natural Resource, Jinka University, Jinka, Ethiopia \\ ${ }^{2}$ Department of Animal and Range Sciences, College of Agriculture and Natural Resource, Madda Walabu University, Bale-Robe, Ethiopia \\ ${ }^{3}$ Department of Animal Sciences, College of Agriculture, Wollo University, Dessie, Ethiopia
}

\section{Email address:}

derbiealemu12@gmail.com (D. Alemu), t.termias@yahoo.com (E. Tekletsadik),mekonnenyirga474@gmail.com (M. Yirga), melakutareke@gmail.com (M. Tareke)

${ }^{*}$ Corresponding author

\section{To cite this article:}

Derbie Alemu, Ermias Tekletsadik, Mekonnen Yirga, Melaku Tareke. Feed Resources Potential and Nutritional Quality of Major Feed Stuffs in Raya Kobo District, North Wollo Zone, Ethiopia. International Journal of Animal Science and Technology. Vol. 3, No. 1, 2019 , pp. $20-29$. doi: $10.11648 /$ j.ijast.20190301.13

Received: April 24, 2019; Accepted: May 28, 2019; Published: June 10, 2019

\begin{abstract}
Using multi-stage purposive sampling technique, 270 households who owned cattle were selected from three agro-ecologies to assess feed resources potential and to evaluate the nutritional quality majorly used feed resources. Structured questionnaire, field observation and focus group discussion were used to collect detailinformation. Conversion factors were used to quantify each feed recourse yield potential per a year in the district. Ten majorly usedcattle feed sampleswere taken to evaluate their nutritional quality. Collected data were analyzed using SAS version 9.2 software packages. Natural pastures, crop residues, stable grazing and hay were the available feed resources in the study area. The cattle population in the district was estimated 1,520 TLU which required an estimated of 13,871 tons of DM for maintenance per annum. The overall estimated DMYof the feed resources in the district was 366,719 tons per year. By assuming 20\% of the feed resources wasted during transportation, storage and feeding, 293,375 tons of DM could be utilized as livestock feed per annum. Major feed resources in the district were grouped under poor quality. In conclusion, the feed resources potential in the district could satisfy the cattle population DM maintenance requirement. However, whether the remaining DMY could satisfy the DM requirement of the entire livestockpopulationin the district needs further investigation. The nutritional quality of feed resources needs improvement through treatment. Moreover, supplementary feeding is needed to satisfy the entire nutrientrequirements of the livestock population in the district.
\end{abstract}

Keywords: Cattle, Feed Resource, Nutritional Quality, Potential, Raya Kobo

\section{Introduction}

Livestock production in Ethiopia closely linked with the economic, social and cultural life of millions poor farmers. Due to a wide diversity of topography, climate and cultural conditions make it difficult to generalize livestock production systems in the country. However, different scholars used different criteria to classify livestock production systems in Ethiopia [37]. The Ethiopian highland areas hold more than $85 \%$ of the total human population and about two thirds of the livestock population, wherecrop-livestock production system is dominantly practiced butbecause of declining of cultivated areas per household, land degradation, reduced feed availability and poor nutrition, the system is recognized under stress [10]. The Ethiopian lowland areas support 12\% of the human and $26 \%$ of the livestock population where livestock production system is subsistence type for milk and/or meat production $[3,5,63]$.

Natural pasture and crop residue feed resources contribute the largest share for livestock feedings in Ethiopia [52]. However, the critical nutrient (crude protein) of herbaceous 
plants declines during the dry season leading to undernutrition of livestock under prolonged periods [59]. Moreover, farmers' adoption and use of improved feed technologies are limited; besides, feed shortage has resulted in a decline of animal products and during serious feed scarcity cases, the death of animals can happen [18]. The recurrent drought and climatic variability has exerted great pressure on the availability of feed resources [9].

Much has been said by many authors about the importance of crop residues as livestock feed in Ethiopia. However, adequate information on the availability of crop residues in relation to their potential for feeding livestock are limited [4]. Much study has not been undertaken on livestock feed resources potential and their nutritional quality in Raya Kobo district. Moreover, for how long the available feed resources can support the cattle maintenance requirement was not studied. In addition, the significance of major feed resources, their nutritional value and related farmer's preferences has not been well studied and documented. Therefore, this study was carried outto assess feed resources potential per year, for how long these feed resourcescould feed the cattle populationina yearand to evaluate the nutritional quality of major feed resources inRaya Kobo district.

\section{Materials and Methods}

\subsection{Description of the Study Area}

The study was conducted in North Wollo Zone of Amhara Regional State in Raya Kobo district (Figure 1), located $579 \mathrm{~km}$ Northeast of Addis Ababa. The district is characterized by bimodal rainfall pattern having three different agro-ecological zones. The main rainy season of the district ranges between June-September while short rainy season ranges from March-May. The district receives a maximum and minimum of $800 \mathrm{~mm}$ and $500 \mathrm{~mm}$ rainfall per annum, respectivelyhaving annual maximum and minimum temperature of $33^{\circ} \mathrm{C}$ and $12^{\circ} \mathrm{C}$ [41]. The dominant soil type of the district is Vertisols with different classifications [41, 49].

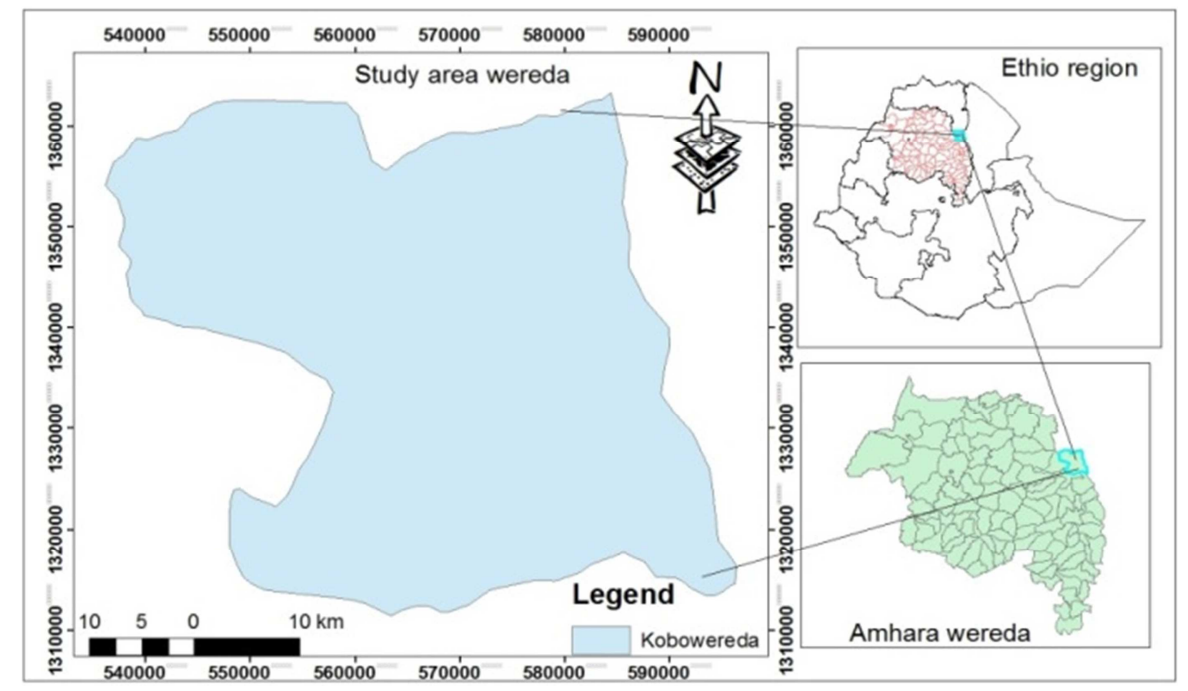

Figure 1. Map of the study area.

\subsection{Sampling Techniques and Sample Size}

Raya Kobo district was selected for this study purposively, because of high cattle population. Using multi-stage sampling technique 9 Kebeles were selected from 45 Kebeles based on their large cattle population. Three Kebeles were randomly selected from highland, midland and lowland agro-ecologies for this study. Multi-stage random sampling method was used to select households. The sample size was determined based on study formula of $0.25 / \mathrm{SE}^{2}$ [8]. The assumption of $3.04 \%$ standard error was used to determine the sample size. From each agro-ecology, 90 households (HHs) were selected (a total of 270) households for this study.

\subsection{Data Source and Methods of Collection}

Both primary and secondary data were used. Primary data were collected using face to face interview, focal group discussion and field observations. For primary data collection, structured questionnaire was developed and pre-tested and adjusted before the commencement of the interview. Data were collected on land use, cattle herd size per household, available feed resources and feeding calendar. Focus group discussion was employed to prioritize feed resources potential and their seasonal variation. Secondary data were collected from Raya Kobo district Agricultural Office and Sirika Agricultural Research Center.

\subsection{Quantifying Feed Resources}

To quantify natural pasture, the sum of privately owned grazing lands (ha) per household and the communal grazing lands (ha) were used. The annual DM output from natural pasture was estimated 2 tons per hectare [24]. Dry matter yield of the entire crop residues produced per year was quantified by using multipliers or conversion factors based on their grain yields. Hence, a multiplier of 1.5 was used for cereal crops and 1.2 multiplier was assumed for pulses crops 
as suggested by the study [24]. For estimation of DM output from maize stover, a multiplier of 2 was employed as proposed by the study [21]. The study assumed $20 \%$ of the entire feed resources could be wasted during transportation, storage and feeding. Since the nutritional qualities the feed resources in the district were poor quality (Table 5), the quantity of dry matter intake (DMI) for maintenance [31] was estimate by $2 \%$ per TLU per day and then it was converted for the entire livestock population found in the district over the year.

\subsection{Feed Sampling and Samples Preparation}

Feed resources in the district were listed and major feed resources were identified based on their majorly used for cattle feeding and farmers preference. Based on these 10 major feed resources were identified and representative samples were taken. Representative samples were collected during subsequent data collection period. Feed samples were stratified into their types and ago-ecologies where they were collected, and were put in the sampling bag labeled. Then the same types were bulked together based on agro-ecology basis, thoroughly mixed and about $2 \mathrm{~kg}$ each feed samples were taken to animal nutrition laboratory for their nutritional composition analysis.

\subsection{Nutritional Quality Analysis}

Feed samples were oven dried at $65^{\circ} \mathrm{C}$ for 72 hours and ground to pass through a one-millimeter sieve size. The nutritional compositionswere analyzed for DM, CP and ash content according to AOAC standards [7]. The fiber fractions (NDF, ADF and ADL) were analyzed according to a study [55]. The analysis was done in three replicates for feed each feed sample.

\subsection{Data Management and Analysis}

The collected data were coded in SAS version 9.2 software packages. Descriptive statistics was employed to describe the various variables. Chi-square test was used for qualitative data to see their significant differences. Similarly, Analysis of variance (ANOVA) procedures was employed for quantitative data sets.

\section{Resultsand Discussion}

\subsection{Landholding and Utilization}

There were significant $(\mathrm{P}<0.001) \quad$ landholding variationacross the study agro-ecologies (Table 1). The overall cropping landholding per household was significantly higher than landholding for homestead and grazing purposes. Of the total land owned by households in South Western Ethiopia, crop cultivation covers about $62.9 \%$ while $10.7 \%$ is allocated for livestock grazing [17]. Farmers in Jimma Zone, Southwest Ethiopia allocate larger proportion of their land for crop production [30]. In Adami Tulu district, central Ethiopia, about $69 \%$ of the land is allocated for crop cultivation while the rest is allocated for private grazing land, homestead land and enclosed plantation/wood land [20]. The average crop land landholding owned per household in lowland area was significantly higher. This might be the low human population density residing in the area. In agreement, better landholding of farmers in low altitudes might be expansion of farmland without restriction by clearing of forest and low population density [14].

The current study overall average landholding per household (1.39ha) was higher than reported in Goma district (0.93ha) of Jimma zone of Ethiopia [16]. It was less than reported in Alaba district (2.55ha) of Southern zone of Ethiopia [60]. It was less than reported in North Gonder (3.28ha) of Ethiopia [46]. Similarly, less than that reported in Jimma Zone (2.14ha) of Southwest Ethiopia [17, 30]. In general, the overall landholding per household in this study (1.39ha) was lower than the reportednational average (2.5ha) landholding [18]. Similarly, reported by different authors in different parts of Ethiopia but higher than the reported national average 1.14ha [19]. These differences indicate the population density difference in different rural areas of Ethiopia. The whole indicates, Raya Kobo is densely populated and this might cause shortage of feed resources for livestock. The contribution of natural pasture to livestock feeds is generally declining due to expansion of crop farming [29]. Frequent occurrence of drought, population pressureand cropland expansion account for the major causes of feed resource shortage in Daro Labu district, Western Hararghe Zone [22].

Table 1. Ndholding per households in the study area.

\begin{tabular}{|c|c|c|c|c|c|}
\hline \multirow{2}{*}{ Parameters } & \multicolumn{5}{|c|}{ Agro-ecology } \\
\hline & Lowland & Mid-altitude & Highland & Overall mean & P-value \\
\hline Homestead land (ha) & $0.01(0.01)^{\mathrm{b}}$ & $0.16(0.01)^{\mathrm{a}}$ & $0.14(0.12)^{\mathrm{a}}$ & $0.10(0.05)$ & $<.0001$ \\
\hline Cropping land (ha) & $1.32(0.06)^{\mathrm{a}}$ & $0.96(0.05)^{b}$ & $0.58(0.04)^{\mathrm{c}}$ & $0.95(0.05)$ & $<.0001$ \\
\hline Grazing land (ha) & $0.33(0.01)^{\mathrm{ab}}$ & $0.27(0.01)^{b}$ & $0.35(0.03)^{\mathrm{a}}$ & $0.34(0.02)$ & $<.0001$ \\
\hline Overall land (ha) & 1.66 & 1.39 & 1.07 & 1.39 & \\
\hline
\end{tabular}

Values outside and inside the parenthesis are mean and standard error, respectively; Means across the raw having different superscript are significantly different.

\subsection{Cattle Population}

There were no significance difference $(\mathrm{p}>0.05)$ calves and lactating cows owned per household across agro-ecologies in the study district (Table 2). There was a significant difference
$(\mathrm{P}<0.001)$ oxen owned per household between the study agroecologies. Overall, the average oxen owned per household was higher than the rest cattle herd structure. This was due to oxen were directly related with crop farming activities. In agreement, oxen are highly demanded for cultivation and other farm 
activities in Burie Zuria District, North Western Ethiopia [14]. Male calves are grown for traction purpose in South Western Ethiopia [17]. The overall average lactating cows and calves owned per household were higher as compared to heifers and bulls owning. The reason was farmers aimed to produce more milk for their family consumption and income. The average overall cattle owned per household in the current study (5.63 TLU) was similar to 5.65 TLU per household in South
Western Ethiopia [17]. But lower than 7.32 TLU per household reported in Debremarkos district [58] and 9.87 TLU per household reported in Alaba district southern Ethiopia [60]. It was higher than 5.10 TLU per household reported in Jimma Zone, Southwest Ethiopia [30]. It was higher than 4.74 TLU per household reported in Kersa, Omo Nada and Tiro Afeta districts of Jimma zone [38].

Table 2. Cattle herd structure owned per household (TLU), overall cattle TLUand estimated maintenance DM required (tons) per year in the study district.

\begin{tabular}{|c|c|c|c|c|c|c|}
\hline \multirow{2}{*}{ Herd category } & \multicolumn{3}{|c|}{ Agro-ecology } & \multirow{2}{*}{ Overall mean } & \multirow{2}{*}{ Overall TLU } & \multirow{2}{*}{ P-value } \\
\hline & Lowland & Mid-altitude & Highland & & & \\
\hline Calves & $0.44(0.12)^{\mathrm{a}}$ & $0.35(0.09)^{\mathrm{a}}$ & $0.38(0.08)^{\mathrm{a}}$ & $0.39(0.10)$ & 105.3 & 0.2467 \\
\hline Heifers & $1.11(0.11)^{\mathrm{a}}$ & $0.66(0.10)^{b}$ & $0.49(0.07)^{b}$ & $0.75(0.10)$ & 202.5 & $<.0001$ \\
\hline Bulls & $1.10(0.09)^{\mathrm{a}}$ & $0.64(0.09)^{b}$ & $0.50(0.07)^{b}$ & $0.75(0.08)$ & 202.5 & $<.0001$ \\
\hline Oxen & $2.64(0.09)^{\mathrm{a}}$ & $2.00(0.08)^{\mathrm{b}}$ & $1.21(0.09)^{\mathrm{c}}$ & $1.95(0.08)$ & 526.5 & $<.0001$ \\
\hline Dry cows & $1.03(0.08)^{\mathrm{a}}$ & $0.62(0.08)^{b}$ & $0.59(0.07)^{\mathrm{b}}$ & $0.74(0.07)$ & 199.8 & $<.0001$ \\
\hline Lactating cows & $1.22(0.12)^{\mathrm{a}}$ & $0.92(0.10)^{\mathrm{a}}$ & $1.02(0.08)^{\mathrm{a}}$ & $1.05(0.10)$ & 283.5 & 0.0986 \\
\hline \multicolumn{5}{|c|}{ Estimated feed DM required per day (tons) } & 30.4 & \\
\hline \multicolumn{5}{|c|}{ Estimated feed DM required per year (tons) } & 13871.0 & \\
\hline
\end{tabular}

Values outside and inside the parenthesis are mean and standard error, respectively; Means across the raw having different superscript are significantly different.

\subsection{Feed Resources Potential}

Natural pasture, crop residues, crop aftermath, thinning of maize and sorghum were major feed resources in Raya Kobo district. In the lowland and mid-altitude agro-ecologies, sorghum and maize thinning was mainly practiced during wet season. Farmers used thesethinningto feed their livestock. To some extent hay was the available feed resource in the highland agro-ecology. This was due to the presence of closure areas in the highland mountainous areas that used for pasture production. Crop residue, stubble grazing and natural pasture are the main feed resources in Jimma Zone, Southwest Ethiopia [30]. Crop residues contribute the largest portion of feed DM followed by natural pasture and cut and carry hay in Burie Zuria District, North Western Ethiopia [14]. Natural pasture, crop residues, crop aftermath are the main feed resources in Gasera and Ginnir Districts, Bale Zone, Ethiopia [26].

\subsubsection{Natural Pasture}

Natural pasture was first most important source of feed for their cattle in the highland and mid-altitude agro-ecologies of the study area. It was abundant during wet seasons especially from July and October. Communal and private pastureland, roadside and swampy areas were the sources of natural pasture. Similar finding was reported in Essera of Woreda, Dawuro Zone in south part of Ethiopia and in South Western Ethiopia $[6,17]$. The status of communal grazing land differs in the study agro-ecologies. Overall, $54.65 \%$ of HHs used communal grazing land to graze their cattle. Majority of respondents $(78.65 \%$ in highland), $(86.67 \%$ in mid-altitude) and $(83.33 \%$ in lowland) areas replied that the size of communal grazing land was decreasing over years. They believed population growth and settlement (42.38\%) and the consequent explanation of farming land $(57.62 \%)$ were the major reasons.

\subsubsection{Crop Residues}

In Raya Kobo district crop residues were mainly used to feed livestock, but few households used crop residues as alternatively fuel source, roof shatter and for construction. Maize Stover, teff straw, sorghum stover, wheat straw and barley straw were the major crop residues used for cattle feeding in the study area. Crop residues were abundantly produced during crop harvesting seasons between January and February. As indicated in the Table 3, teff straw and sorghum stover were dominantly available in lowland and mid-altitude agro-ecologies, whereas, barley straw and wheat straw were dominantly available in the highland area. In Gasera and Ginnir Districts, Bale Zone, Ethiopia, crop residues are the main source of feed (contribute more than $80 \%$ ) during the dry season from early February to June when pasture from grazing area not able to provide reasonable quantity of feed [26]. Crop residues are the major feed source in dry season in South Western Ethiopia [17]. Similarly, crop residues are the major feed resources in Essera of Woreda, Dawuro Zone in south part of Ethiopia [6]. Crop residues contribute up to $30-80 \%$ of the total feed DM available for animals in the highlands of Ethiopia [1].

\subsubsection{Crop Aftermath}

Crop aftermath/stubble grazing was the most important feed resource of cattle feed next to crop residues. After harvesting the crops, cattle were allowed to graze stubbles of maize, sorghum, teff, wheat, barley and pulses between October and December. Farmers used aftermath grazing as one means to sustain their cattle before they started feeding of collected crop residues. The land owners only allowed their cattle to graze on the stubbles for first two months. Then other neighboring community could graze their cattle after two months. In agreement, stubbles are accessible to livestock owned by individual farmers for the first two 
months in central highlands of Ethiopia, and later it becomes accessible to all animals in the community [46]. Crop aftermaths are the major feed source in dry season in South Western Ethiopia [17]. They are major source of feed frommid July to late August during short rainy season and from November to April in Gasera and Ginnir Districts, Bale Zone, Ethiopia [26].

\subsubsection{Ranks of Crop Residues}

The major crops grown by farmers in the highland areas were barley, wheat, teff, sorghum and pulse crops. Whereas, teff, maize, sorghum were the main crops grown in medium and lowland agro-ecologies. Cattle feed resources were ranked depending on their abundance and availability for cattle feeding. Majority of HHs used teff straw and sorghum stover as feed resources. The index shows (Table 3 ) that teff straw was $1^{\text {st }}$ ranked feed resource in lowland and midland agro-ecologies followed by sorghum stover. Similar study was reported in Wagmhra zone of Sekota district [62]. Focus group discussion with key informantinterview indicated that availability of crop residues varied among the agro-ecological zones.

Table 3. Ranks of major crop residues utilized in the study area.

\begin{tabular}{|c|c|c|c|c|c|c|c|c|}
\hline \multirow{2}{*}{ Agro ecology } & \multirow{2}{*}{ Crop residue } & \multicolumn{7}{|l|}{ Rank } \\
\hline & & $1^{\text {st }}$ & $2^{\text {nd }}$ & $3^{\text {rd }}$ & $4^{\text {th }}$ & $5^{\text {th }}$ & $6^{\text {th }}$ & Index \\
\hline \multirow{6}{*}{ Lowland } & Wheat straw & - & - & - & 27.8 & 33.3 & 38.9 & 0.09 \\
\hline & Barley straw & - & - & & 38.9 & 33.3 & 27.9 & 0.101 \\
\hline & Teff straw & 50 & 27.77 & 22.22 & - & - & - & 0.251 \\
\hline & Pulse haulms & - & - & - & 33.3 & 33.3 & 33.3 & 0.095 \\
\hline & Maize stover & 22.22 & 22.22 & 55.55 & - & - & - & 0.222 \\
\hline & Sorghum stover & 27.78 & 50 & 22.22 & - & - & - & 0.241 \\
\hline \multirow{5}{*}{ Mid-altitude } & Wheat straw & - & 11.1 & 22.2 & 25.6 & 30 & 11.1 & 0.139 \\
\hline & Barley straw & 5.6 & 25.6 & 27.8 & 14.4 & 11.1 & 4.4 & 0.163 \\
\hline & Teff straw & 50 & 38.9 & 11.1 & - & - & - & 0.257 \\
\hline & Pulses haulms & - & - & - & 38.9 & 27.8 & 33.3 & 0.098 \\
\hline & Maize stover & - & - & 38.9 & 21.1 & 5.6 & 45.6 & 0.131 \\
\hline \multirow{7}{*}{ Highland } & Sorghum stover & 44.4 & 24.4 & - & - & 25.6 & 5.6 & 0.212 \\
\hline & Wheat straw & 22.2 & 27.8 & 22 & 16.6 & 11.1 & - & 0.206 \\
\hline & Barley straw & 27.8 & 33.3 & 23.3 & 22.2 & 15.6 & - & 0.25 \\
\hline & Teff straw & 27.8 & 16.6 & 17.8 & 26.7 & 11.1 & - & 0.202 \\
\hline & Pulses haulms & - & - & 22.2 & - & 22.2 & 44.4 & 0.086 \\
\hline & Maize stover & - & - & - & - & 40 & 55.6 & 0.065 \\
\hline & Sorghum stover & 22.2 & 22.2 & 14.4 & 34.4 & - & - & 0.193 \\
\hline
\end{tabular}

\subsubsection{Improved Forages}

All respondents $(100 \%)$ used for this study didn't cultivate improved forages. The major reasons were shortage of land and lack of awareness. All households (100\%) in Dandi district do not cultivate improved forages to feed their livestock [13]. Only 13.3\% households cultivate and use improved forages in Daro Labu district, Western Hararghe Zone [22]. Majority of the respondents (68.4\%) in South Western Ethiopia do not practice forage cultivation [17]. About 74.4\% households in Meta-Robi District, West Shewa Zone, Oromia Regional State, Ethiopia do not produce improved forage [56]. Land scarcity in crop-dominated farming limits the introduction of improved pasture and forages in different agro-ecologies of Ethiopia [35]. Expansion of crop land, increased human population and lack of knowledge are the limiting factors of forage crop production in Bacho, Algie and Chewaka of Ilu Aba Bora zone [50].

\subsection{Feed Resources Calendar}

Respondents in the current study classified months of the year according to feed availability. Excess availability of feed resources months of the year was associated with rainy season and crop harvesting season. Natural pasture was mostly available between July to October (Figure 2) but livestock were allowed to graze starting from the mid of September whereas, crop residues wereabundantly available between March to July. During dry season, cattle were largely depends on crop residues. Although, natural pasture and crop residues were the major feed sources, there was a seasonal fluctuation in their availability and quality. As a result serious cattle body weight losswas a common phenomenon in the study area. Crop residues and stubble grazing are the major feed resources during the dry season in Burie Zuria District, North Western Ethiopia [14]. Seasonal variations in feed quality and quantity are the main limitation to animal production and cause fluctuation in productivity throughout the year in Belesa Woreda of Amhara Region [48]. Feed resources availability shows seasonal variations in Jimma Zone, Southwest Ethiopia [30]. When pasture can't able to provide reasonable quantity feed, crop residues are the main source of feed during dry season from early February to June and aftermath grazing is common from mid July to late August during short rainy season and from November to April in Gasera and Ginnir Districts, Bale Zone, Ethiopia [26]. Crop residues and crop aftermath are the major feed source in dry season in South Western Ethiopia [17]. The availability of feed resources in the highlands depends on the intensity of crop production, population pressure, the amount of rainfall, and distribution pattern of rainfall and seasons of the year [43]. Climatic variability has exerted great pressure on the availability and use of feed resources in Ethiopia [9]. 


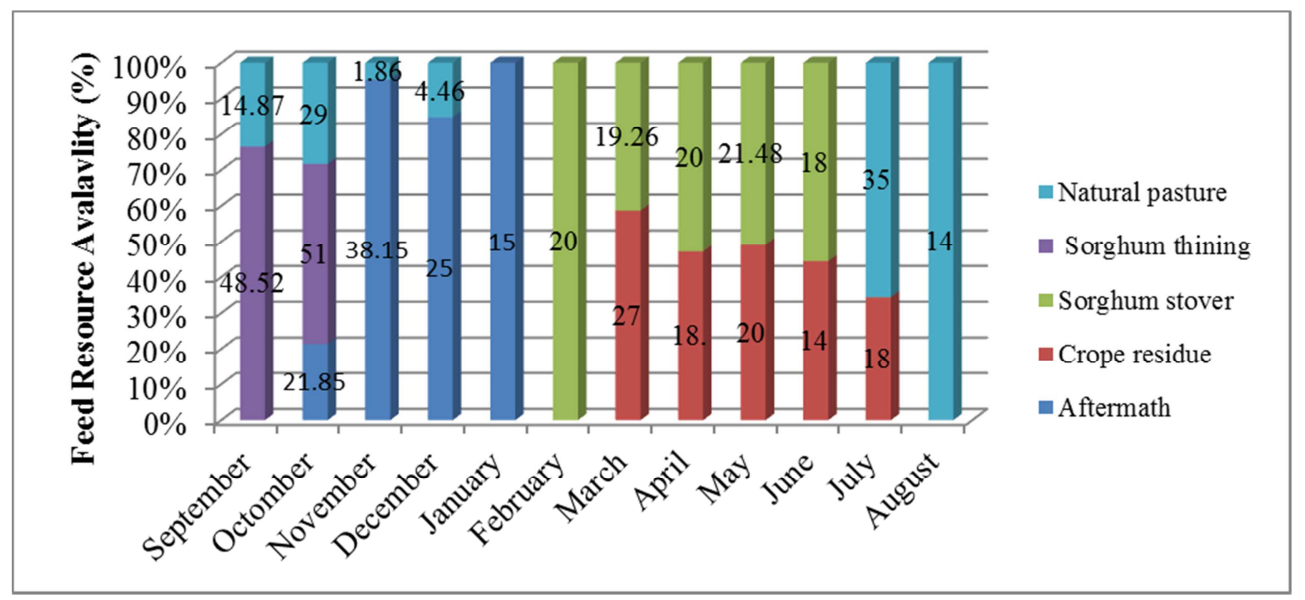

Figure 2. Months of feed resource availability in the study area.

In the study area, feed resources were surplus between October and January, sufficient between February and May (Figure 3). Feed shortage was very common during cropping season (between July and September). This is because during these months, stored crop residues were almost utilized and, private and communal grazing lands were not allowed for grazing until mid of September. Similar finding is reported in Jimma Zone Southwestern Ethiopia [32]. Feed shortage has remained to be the most limiting factor of livestock production in the highlands of Ethiopia [28]. The most critical periods are from February to May, when all feed resources are virtually depleted, and conservation of crop residues is inadequate in the highland of Ethiopia [57]. Crop thinning plants are the primary sources of feed in the wet season in Daro Labu district, Western Hararghe Zone and in Jimma Zone, Southwest Ethiopia [22, 30]. In wet season natural pasture is a major source of feed which is highly supported by tinned cereal crops like maize and weed materials in South Western Ethiopia [17]. In Baresa watershed, Meskan Woreda of Gurage Zone of Ethiopia farmers use high seeding rate of maize so that maize population is high enough for thinning and to be used as a feed source during the rainy season [36].

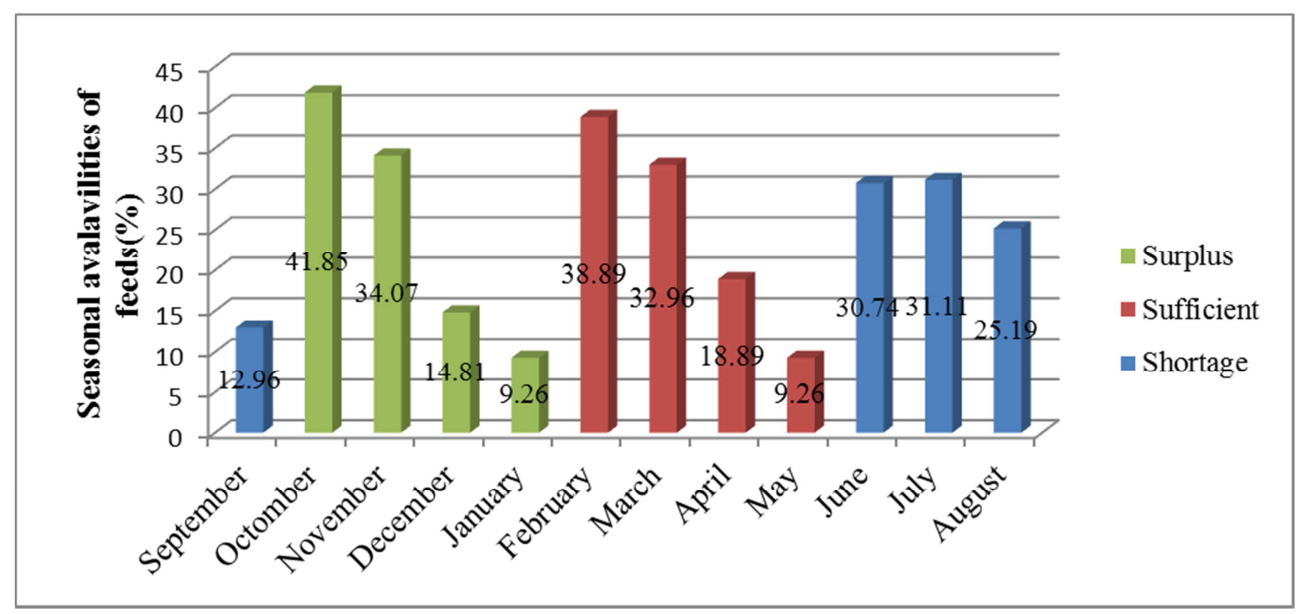

Figure 3. Seasonal availability of feed in the study area.

\subsection{Feed Resources Potential}

Mixed farming system was the main activity practiced inthe study area. Usually crops were cultivated and consequently different types of crop residues were produced. The major crop residues used as livestock feed came from sorghum, teff, maize, barley and pulses. The DM yield produced from sorghum stover was 246,637 tons per year (Table 4). Greater sorghum stover production indicatesthe district had a potential for sorghum production. The overall estimated DMY of the feed resources in the district was 366,719 tons per annum.

As indicated in Table 2, the overall cattle population in the district was estimated $1520 \mathrm{TLU}$ which required an estimated of 11,097 tons of DM per annum for maintenance, even though, DM intake can be affected by animal body weight, health condition, production status, environmental conditions and forage quality. About $70 \%$ crop residues can utilized as livestock feed [52]. By assuming 20\% of the feed resources wasted during transportation, storage and feeding, 293,375 tons of DM could be utilized as cattle feed in the study district per year. This indicates the feed resources potential produced in the district could satisfy the cattle populationannual DM requirement for maintenance. An estimated of 11.44 tons DM feed resource is produced per $\mathrm{HH}$ in Jimma Zone, Southwest Ethiopia and it can satisfy 
only $39.59 \%$ of the annual maintenance DM requirement of livestock units per $\mathrm{HH}[30]$.

\subsection{Nutritional Quality of Major Feed Resources}

There were a significant variations $(\mathrm{P}<0.001)$ in the nutritional compositions among majorly used feed resources for cattle feeding in Raya Kobo district (Table 5). The overall nutritional compositions of the feed resources were in the range of Ethiopian common feeds nutritional compositions reported [12]. Less nutritional composition variation was observed in the DM contents. The $\mathrm{CP}$ content of the feedstuffs was significantly $(\mathrm{P}<0.001)$ very variable as compared to other nutrients variations. Differences might be attributed to varietal differences, harvesting time and methods of processing [23]. Major feed resources show a great variation in chemical composition in seasonality in crop-livestock mixed farming systems of southern Ethiopia [47]. Comparable CP, ADF, NDF and ADL chemical composition is reported for similar feed resource types in Gasera and Ginnir Districts, Bale Zone, Ethiopia [26].

Table 4. Quantified feed resources (DM) in Raya Kobo district per annum.

\begin{tabular}{llllll}
\hline Crop residues & Cultivated area (ha) & $\begin{array}{l}\text { Average grain } \\
\text { yield/ha (Qt) }\end{array}$ & $\begin{array}{l}\text { Total grain yield } \\
\text { (Tons) }\end{array}$ & Conversion factor & $\begin{array}{l}\text { Crop residue } \\
\text { DMY (Tons) }\end{array}$ \\
\hline Sorghum stover & 18696 & 65.96 & $123,318.8$ & 2 & $246,637.6$ \\
Maize stover & 3100 & 67.72 & $20,993.2$ & 2 & $41,986.4$ \\
Teff straw & 11449 & 18.80 & $21,524.1$ & 1.5 & $32,286.2$ \\
Wheat straw & 3019 & 43.58 & $13,156.8$ & 1.5 & $19,737.2$ \\
Barley straw & 2434 & 31.78 & $7,735.3$ & 1.5 & $11,602.9$ \\
Lentil haulm & 678 & 32.63 & $2,212.3$ & 1.2 & $2,654.8$ \\
Field pea haulm & 1300 & 8.34 & $1,084.2$ & 1.2 & $1,301.0$ \\
Chickpea haulm & 301 & 28.50 & 857.9 & 1.2 & $1,029.4$ \\
Faba bean haulm & 15 & 14.5 & 21.8 & 1.2 & 26.1 \\
Naturalpasture & 15049.4 & - & - & 0.5 & $7,525.7$ \\
Forest pasture & 954.3 & - & - & 1.7 & $1,622.3$ \\
Crop aftermath & 154.8 & - & - & 2 & 309.6 \\
Overall estimated DMY & & & & & $366,719.2$ \\
Expected wastage (20\%) & & & & $73,343.8$ \\
Expected utilization by livestock & & & & $293,375.4$ \\
\hline
\end{tabular}

According to [21, 24] conversion factors.

Table 5. Mean nutritional quality of majorly used feed resources in Raya Kobo district.

\begin{tabular}{|c|c|c|c|c|c|c|}
\hline \multirow{2}{*}{ Feed sample } & \multicolumn{6}{|c|}{ Parameters } \\
\hline & DM & Ash & $\mathbf{C P}$ & NDF & ADF & ADL \\
\hline Highland barley straw & $93^{\mathrm{b}}$ & $10.75^{\mathrm{b}}$ & $4.44^{c}$ & $79.57^{\mathrm{f}}$ & $60.22^{\mathrm{e}}$ & $17.68^{\mathrm{bc}}$ \\
\hline Highland wheat straw & $93^{\mathrm{b}}$ & $7.53^{\mathrm{e}}$ & $2.44^{\mathrm{g}}$ & $81.72^{\mathrm{de}}$ & $62.33^{\mathrm{d}}$ & $17.69^{\mathrm{bc}}$ \\
\hline Highland sorghum stover & $93^{\mathrm{b}}$ & $9.68^{\mathrm{c}}$ & $2.81^{\mathrm{ef}}$ & $75.68^{\mathrm{g}}$ & $56.86^{\mathrm{f}}$ & $14.56^{\mathrm{d}}$ \\
\hline Highland teff straw & $92^{\mathrm{c}}$ & $7.61^{\mathrm{e}}$ & $3.16^{\mathrm{d}}$ & $76.09^{\mathrm{g}}$ & $54.35^{\mathrm{g}}$ & $13.54^{\mathrm{d}}$ \\
\hline Midland sorghum stover & $92^{\mathrm{c}}$ & $14.79^{\mathrm{a}}$ & $4.59^{c}$ & $82.61^{\mathrm{dc}}$ & $60.87^{\mathrm{e}}$ & $16.67^{\mathrm{c}}$ \\
\hline Midland teff straw & $93^{\mathrm{b}}$ & $6.45^{\mathrm{f}}$ & $5.34^{\mathrm{b}}$ & $83.87^{\mathrm{bc}}$ & $53.76^{\mathrm{g}}$ & $14.56^{\mathrm{d}}$ \\
\hline Lowland sorghum stover (Abola) & $93^{\mathrm{b}}$ & 6.45 & $2.56^{\mathrm{g}}$ & $84.48^{\mathrm{b}}$ & $66.33^{\mathrm{b}}$ & $18.64^{\mathrm{b}}$ \\
\hline Lowland teff straw & $94^{\mathrm{a}}$ & $7.45^{\mathrm{e}}$ & $6.03^{\mathrm{a}}$ & $80.85^{\text {fe }}$ & $54.23^{\mathrm{g}}$ & $14.56^{\mathrm{d}}$ \\
\hline Lowland maize stover & $93^{b}$ & $8.60^{\mathrm{d}}$ & $2.94^{\mathrm{e}}$ & $83.87^{\mathrm{bc}}$ & $69.46^{\mathrm{a}}$ & $19.72^{\mathrm{a}}$ \\
\hline Level of significant & $* * *$ & $* * *$ & $* * *$ & $* * *$ & $* * *$ & $* * *$ \\
\hline
\end{tabular}

${ }^{\mathrm{Abcdefg}=}$ means with different superscripts within a column are significantly different; $* * *=\mathrm{P}<0.001 ; \mathrm{ADF}=\mathrm{Acid}$ detergent fiber; $\mathrm{ADL}=\mathrm{Acid}$ detergent lignin; $\mathrm{CP}=$ Crude protein; $\mathrm{DM}=$ Dry matter; $\mathrm{NDF}=$ Neutral detergent fiber.

\subsection{Crude Protein Content}

Mean CP content of wheat straw and barley straw was $2.44 \%$ and $4.48 \%$, respectively in the highland agroecology of the study district. This indicates barley straw had a better source CP in highland area of the study district, whereas, Teff straw and sorghum stover were better source of CP in midland and lowland area of the study district. The mean CP content of barley straw and wheat straw is similar with the report of the study that is $4.4 \%$ for barley straw and $2.4 \%$ for wheat straw in Addis Ababa area of Ethiopia [44]. A little bit better CP content of wheat straw (2.7\%) is reported in the central highlands of Ethiopia [25]. This may be due to varietal differences and variation in management practices as well as soil fertility differences in the study areas.

All crop residues in the study agro-ecologies had less than the critical level (7\%) of CP required for optimum microbial rumen function. The optimum $\mathrm{CP}$ required for microbial rumen function should be greater than $7 \%$ and feeds that haveless than $7.5 \% \mathrm{CP}$ level inhibits voluntary feed intakes and the activity of microbial action declines, resulting in lower digestibility of roughages [54]. The microbial protein synthesis is for ruminants feed on low in low-quality forages [40]. The minimum $15 \% \mathrm{CP}$ required for lactation and growth of ruminants [39]. This indicates the entire crop 
residues evaluated in the study area were by far below the $\mathrm{CP}$ requirement for maintenance and production, indicating the need of supplementary feeding. A mixture of forages and concentrates increases the efficiency of microbial protein synthesis [40].

\subsection{Fiber Fraction}

Neutral detergent fiber (NDF) ranges from $75.68 \%$ to $86.75 \%$ with a significant $(\mathrm{P}<0.001)$ variation among feedstuffs. These variations might be related to crop difference and crop maturity in the study area that provides chance for fiber accumulation in plant tissues. The NDF contents of crop residues are close to previous reported for central highlands of Ethiopia [44]. Roughage feedshaving NDF content of with less than $45 \%$ are grouped as a high quality feed, while feed with NDF content of $45-65 \%$ are categorized as medium quality feed [45]. Forage DMI is more correlated with NDF than with any other chemical component and rumen volume is affected by forage NDF and when NDF content above 55\% limit DM intake [54]. This indicates the major feed resources used for cattle feeding in Raya Kobo district were grouped under poor quality and they could limit the DMI which directly affect the productivity of livestock in the study area.

The ADF content was significantly different $(\mathrm{P}<0.001)$ among the feedstuffs. The current study ADF contents of crop residues was close to the feed resources ADF content in central highlands of Ethiopia [43]. But it was higher than natural pasture in central part of Ethiopia, who observed the increment of ADF from 35.1 to $41.4 \%$ as cutting date increases [33]. The acid detergent lignin (ADL) content for barley straw and wheat straw were $17.68 \%$ and $17.69 \%$, respectively. The ADL content straw and wheat straws were lower as compared to stovers of maize and sorghum. Wheat and barleystraw and maize stover ADL content in current study was higher than reported in Awasa Woreda, Sidamo Zone Southern of Ethiopia [61]. This may be associated with varietal, climate and crop management differences in the area.

\section{Summary and Conclusion}

Rapid population growth, farm land expansion and population settlement were the causes of grazing land size reduction and productivity in Raya kobo district. Natural pasture was first most important source of feed for cattle in the highland and mid-altitude agro-ecologies mainly from mid of September to October. Next to natural pasture, aftermath, crop residues and sorghum stover were important feed resources from November to mid of September. Teff straw, barley straw and sorghum stover were majorly used by HHs to feed their cattle. Teff straw was the first ranked preferred crop residue in all ago-ecologies of the study area. Feed shortage was more critical during August and September.

The overall estimated DMY of the feed resources in Raya Kobo district was estimated 366,719 tons per annum. By assuming $20 \%$ feed resource wasted during transportation, storage and feeding, the feed potential produced per year in the district could satisfy the cattle population DM requirement for maintenance. However, whether the remaining DMY could satisfy the DM requirement of other livestock species needs further investigation.

The nutritional compositions of the majorly used feed resourcesfor cattle feeding in the study districtshow significant $(\mathrm{P}<0.001)$ variations. Crude protein content was the wide nutrient variation $(\mathrm{P}<0.001)$ among the feedstuffs. The entire crop residues evaluated had low CP below therequirement for maintenance and production. The NDF content the feed resources is very high $(>65 \%)$. The whole indicates the major feed resources in Raya Kobo district were grouped under poor quality that directly limits productivity of livestock in the study area. Therefore, feed resources needs improvement through treatment and supplementary feeding is needed to satisfy the entire nutrient requirement of the livestock population in the district.

\section{Conflict of Interest Statement}

The authors declare that they have no competing interests.

\section{Acknowledgements}

We thank MaddaWalabu University for granting this study and all livestock professionals and Officials in Raya Kobo District who helped us directly or indirectly during data collection.

\section{References}

[1] Africa RISING (2014). Africa Research in Sustainable Intensification for the Next Generation, Ethiopian Highlands Project Technical report, p: 14.

[2] Alemayehu, M. and A. Sissay (2003). Integrated Livestock Development Project (ILDP) Livestock Feed Resources Survey. North Gondar, Ethiopia. pp. 75.

[3] Alemayehu, M. (2004). Pasture and Forage Resource profiles of Ethiopia. Ethiopia / FAO. Addis Ababa, Ethiopia. Pp 19.

[4] Alemu, Y., Zinash, S. and B. Seyoum (1991). The Potential of Crop Residues and Agro-Industrial By-Products as Animal Feed. In: ESAP Proceedings, Third National Livestock Improvement Conference. 24-26 May 1989. Addis Ababa, Ethiopia. pp 57-63.

[5] Amaha, K. (2006). Characterization of rangeland resources and dynamics of the pastoral production system in the Somali region of eastern Ethiopia. PhD thesis, University of the Free State, Bloemfontein, South Africa. Pp. 232.

[6] Andualem, T., Berhan, T., Gebeyehu, G. and B. Ermias (2015). Characterization of cattle husbandry practices in Essera Woreda, Dawuro Zone.

[7] AOAC (1990). Official methods of analysis of the association of official analytical chemists, 15th edition Association of Official Analytical Chemists (AOAC), Washington, DC. 
[8] Arsham, H. (2007). Questionnaire design and survey sampling. $\mathrm{http} / / \mathrm{www} . \mathrm{mirror}$ edu/ntsbarsh/Business-state.

[9] Assefa, H., Bienen, D. and D. Ciuriak (2013). Ethiopia's Investment Prospects: A Sectorial Overview. African Review of Economics and Finance, 4 (2), 203-246.

[10] Aune J., Bussa M., Asfaw F. and A. Ayele (2001). The ox ploughing system in Ethiopia: can it be sustained? Outlook on Agriculture. 30: 275-280.

[11] Azage, T. (2004). Urban Livestock Production and Gender in Addis Ababa, Ethiopia urban Agriculture Magazine (The Netherlands) ILRI (International Livestock Research Institute) Addis Ababa, Ethiopia pp. 31-32.

[12] Bediye, S., Silashi, Z. and D. Fekadu (2007). Compositionand nutritive value of Ethiopian feedstuff, research report no. 73. Inistiute of Agricultural Research (IAR), Addis Ababa, Ethiopia. pp. 9-19.

[13] Belay D.., Azage T. and B. P. Hegde (2012). Smallholder Livestock Production System in Dandi District, Oromia Regional State, Central Ethiopia. Global Veterinarian 8 (5): 472-479.

[14] Belay, G. and T. Negesse (2018). Feed Resource Availability and their Nutrient Contribution for livestock Evaluated Using Feed Assessment Tool (FEAST) in Burie Zuria District, North Western Ethiopia. Agricultural Research and Technology, 17 (3): 1-10, DOI: 10.19080/ARTOAJ.2018.17.556022.

[15] Belay, S. M. (2009). Feed Resources Availability, Cattle Fattening Practices and Marketing System in Bure Woreda, Amhara Region, Ethiopia. MSc thesis.

[16] Belete, S. (2009). Production and marketing systems of small ruminants in Gomma distric of Jimma zone, south western Ethiopia. MSc. Thesis.

[17] Biratu, K. and S. Haile (2017). Assessment of livestock feed availability, conservation mechanism and utilization practices in South Western Ethiopia. Academic Research J. Agricultural Science and Research, 5 (7): 461-470, DOI: 10.14662/ARJASR2017.074.

[18] CSA (2013). The Federal Democratic Republic of Ethiopia Central Statistics Agency. Agricultural sample survey 2012/13 [2005 E. C]. Vol. II. Report on livestock and livestock characteristics. Addis Ababa, Ethiopia. pp. 188.

[19] CSA (Agricultural Sample Surveys) (2015). Crop yield for major grain crops, private smallholder farms, main season. Addis Ababa, Ethiopia.

[20] Dawit, A, Ajebu, N. and B. Sandip (2013). Assessment of feed resource availability and livestock production constraints in selected Kebeles of Adami Tullu Jiddo Kombolcha District, Ethiopia. African. J. Agricultural Research. 8 (29): 4067-4073.

[21] De Leeuw, P. N., Dzowela, B. H. and R. Nyambaka (1990). Budgeting and allocation of feed resources. In: B. H. Dzowela, A. H. Said, W. Asrat and J. A. Kategile (eds.) Utilization of Research Results on Forage and Agricultural Byproduct Materials as Animal Feed Resource in Africa. Proceedings of $1^{\text {st }}$ PANESA/ARNAB Joint Workshop held in Lilongwe, Malawi, 5 - 9 December 1988. ILCA, Addis Ababa, Ethiopia pp. 222-232.

[22] Debela, M., Animut, G. and M. Eshetu (2017). Assessment of Feed Resources Availability and Utilization in Daro Labu district, Western Hararghe Zone. J. Natural Sciences Research
7 (13): 50-57.

[23] Ermias, T., Solomon, M. and U. Mengistu (2013). The effect of barley bran, linseed meal and their mixes supplementation on the performances, carcass characteristics and economic return of Arsi-Bale sheep. Small Ruminant Research 114 (2013) 35-40.

[24] FAO (1987). Land Use, Production Regions and Farming Systems Inventory. FAO Project ETH/78/003, Addis Ababa, Ethiopia feeds. Paper presented at the 7th AAFARR Workshop, 2-6 July, Chiang Mai.

[25] Gashaw, G. (1992). Assessment of Feed Resource Base and Performance of Crossbred Dairy Cows Distributed to Smallholder in the Selale Dairy Development Project Area. MSc. Thesis, School of Graduate Studies, Alemaya University of agriculture, Alemaya. pp. 171.

[26] Gashaw, M. and G. Defar (2017). Livestock feed resources, nutritional value and their implication on animal productivity in mixed farming system in Gasera and Ginnir Districts, Bale Zone, Ethiopia. International J. Livestock Production, 8 (2): 12-23, DOI: 10.5897/IJLP2016.0297.

[27] Germay, D., Hassen, A., Kocho, T., Berhanu, T., Bassa, Z. and A. Jimma (2013). Chemical Composition and Digestibility of Major Feed Resources in Mixed Farming System of Southern Ethiopia. World Applied Science J. 26 (2): 267-275. DOI: 10.5829/idos.wasj.2013.26.02.1456.

[28] Gizaw, S., Ebro, A., Tesfaye, Y., Mekuriaw, Z., Y. Mekasha (2017). Feed resources in the highlands of Ethiopia: A value chain assessment and intervention options. International Livestock Research Institute (ILRI), Nairobi, Kenya. pp. 50.

[29] Hailemariam, S., Mohamed, A., Silassie, G. M. and K. Gebeyew (2017). Identification and nutritional characterization of major sheep and goats feed resource in Jigjiga zone, Ethiopia Somali regional state. World Applied Sciences J., 35 (3): 459-464.

[30] Husen, M., Kechero, Y. and M. Molla (2016). Assessment of Livestock Feed Resources Utilization in Jimma Zone, Southwest Ethiopia. Academic J. Nutrition 5 (1): 01-17.

[31] Kearl, L. C., (1982). Nutrient requirement of Ruminants in developing countries international feed stuffs institute, Utah Agricultural experiment station, Utah state university 84332. USA, pp: 381

[32] Kechero Y., Tolemariam, T., and Haile, A. (2013). Characteristics and Determinants of Livestock Production in Jimma Zone /Southwestern Ethiopia. African J. Basic \& Applied Sciences 5 (2): 69-81.

[33] Kidane, G.(1993). Effect of Cutting Date on Botanical Composition and Nutritive Value of Native Pasture in the Central Ethiopia. M.Sc. Thesis. Alemaya University of Agriculture, Alemaya. 105 pp.

[34] Mengistu, A., Kebede, G., Assefa, G. and F. Feyissa (2016). Improved forage crops production strategies in Ethiopia: A review. Academic Research J. Agricultural Science and Research, 4 (6): 285-296, DOI: 10.14662/ARJASR2016.036.

[35] Mengistu, A., Kebede, G., Feyissa, F. and G. Assefa (2017). Major Feed Resources in Ethiopia: Conditions, Challenges and Opportunities Review Academic Research J. Agricultural Science and Research, 5 (3): 176-185, DOI: 10.14662/ARJASR2017.013. 
[36] Mergia A., Adugna T. and A. Getnet (2014). Feed resource assessment and utilization in Baresa Watershed, Ethiopia. International J. Science and Research (IJSR).

[37] Mohamed, A., Ahmed, A., Ehui, S. and A. Yemsrach (2004). Dairy Development in Ethiopia. EPTD discussion paper No. 123. International Food Policy Research Institute. Washington, DC. USA. pp. 41.306.

[38] Mohammed, H., Yisehak, K. and M. Meseret (2016). Characterization of livestock production system in three selected districts of Jimma Zone, Southwest Ethiopia. Journal of Reproduction and Infertility. 7 (2): 47-62.

[39] Norton, B. W. (1982). Difference between species in forage quality. In: Proceedings of an International Symposium, St. Lucia, Queensland, Australia, pp. 89-110.

[40] Pathak, A. K. (2008). Various factors affecting microbial protein synthesis in the rumen. Veterinary World, Vol. 1 (6): 186-189.

[41] SARC. (2001). Profile of Sinana Agricultural Research Center Oromia Agricultural Research Institute. Bulletin No. 1, November 2001. pp. 31.

[42] SAS (2002). SAS ${ }^{\circledR} 9.1$, users guide. SAS Institute Inc, Cary, North Carolina.

[43] Seyoum, B., Getinet, A., Abate, T. and F. Dereje (2001). Present status and future direction in feed resources and nutrition research targeted for wheat based crop livestock production system in Ethiopia. In: P. C. Wall (Eds.). Wheat and Weed: Food and Feed. Proceedings of Two Stakeholder Workshops. CIMMYT, Mexico City.

[44] Seyoum, B. and S. Zinash (1989). The composition of Ethiopian feed stuffs, Research Report no. 6. Institute of Agricultural Research (IAR), Addis Ababa, Ethiopia. 33 pp.

[45] Singh, G. P. and S. J. Oosting (1992). A model for describing the energy value of straws. Indian dairy man XLIV: 322-327.

[46] Sisay, A. (2006). Livestock Production Systems and Available Feed Resources in Different Agro-Ecologies of North Gonder Zone, Ethiopia. MSc. Thesis. Pp. 89.

[47] Talore, D. G. (2015). Evaluation of major feed resources in crop-livestock mixed farming systems, southern Ethiopia: Indigenous knowledge versus laboratory analysis results. $J$. Agriculture and Rural Development in the Tropics and Subtropics, 116 (2): 157-166 urn:nbn:de:hebis: 342015061048507.

[48] Tesema, Z., Aklilu, A. and S. Amaha (2003). Assessment of the cattle production system, available feed resources and marketing situation: a case study in drought prone areas of Amhara Region. In: Proceedings of the $10^{\text {th }}$ Annual Conference of the Ethiopian Society of Animal Production (ESAP) held in Addis Ababa, Ethiopia.

[49] Tesfaye, A., M. Githiri, J. Derera and T. Debele (2011). Subsistence farmer's experience and perception about the soil and fertilizer use in Western Ethiopia. Ethiopian J. Applied Sci. Technol., 2: 61-74.

[50] Teshager, A, Belay, D and T. Taye (2013). Socio-economic and farm characteristics of smallholder cattle producers in Ilu Aba Bora Zone of Oromia Regional State, South Western Ethiopia, Global Veterinarian. 10 (5): 607-613.
[51] Tessema, Z., Aklilu, A. and S. Amaha, (2003). Assessment of the livestock production system, available feed resources and marketing situation in Belesa Woreda: A case study in drought prone areas of Amhara Region. In: Proceedings of the 10th annual conference of the Ethiopian Society of Animal Production (ESAP) held in Addis Ababa, Ethiopia, August 2224, 2002. Addis Ababa, Ethiopia. Pp. 165-175.

[52] Tolera, A, Yami, A and D. Alemu (2012). Livestock feed resources in Ethiopia, challenges, opportunities and the need for transformation. Ethiopian animal feed industry Association, Addis Ababa, p: 132.

[53] Tolera, A. (1990). Animal production and feed resource constraints in Wolayita Sodo and the supplementary value of Desmodium intortum, Stylosanthes guianensis and Macrotyloma axillare when fed to growing sheep feeding on a basal diet of maize stover. Master's thesis.

[54] Van Soest, P. J. (1994). Nutritional ecology of the ruminant. 2nd ed. Cornell University Press, Ithaca, USA.

[55] Van Soest, P. J. and Robertson, J. B. and B. A. Lewis (1991). Methods for dietary fiber, neutral detergent fiber and nonstarch polysaccharides in relation to animal nutrition. J. Dairy Sci. 74, 3583-3597.

[56] Yadessa, E., Ebro, A., Fita, L. and G. Asefa (2016). Feed resources and its utilization practices by smallholder farmers in Meta-Robi District, West Shewa Zone, Oromiya Regional State, Ethiopia. Academic Research J. Agricultural Science and Research, 4 (4): 124-133, DOI: 10.14662/ARJASR2016.012

[57] Yami, M., Begna, B. and T. Teklewold (2013). Enhancing the productivity feeding strategies and utilization. International $J$. Livestock Production 1: 15-29.

[58] Yayeh, Z., Hailemariam, H., Belhu, K. and B. Asmare (2014). Characterization of dairy cattle production systems in Debremarkos district, Amhara Regional State, Ethiopia. Pacesetter J. Agricultural Science Research, 2 (4): 42-51.

[59] Yayneshet, T., Eik, L. O. and S. R. Moe (2009). Seasonal variations in the chemical composition and dry matter degradability of exclosure forages in the semi-arid region of northern Ethiopia. Animal Feed Science and Technology, 148 (1): 12-33. DOI: 10.1016/j.anifeedsci.2008.02.003.

[60] Yeshitila, A.(2008). Assessment of Livestock Feed Resources Utilization in Alabaworeda. Southern Ethiopia, MSc. Thesis.

[61] Yitaye A. (1999). A Study on Livestock ProductionSystem, Feed Resourceand FeedAllocation PracticesinthreePAs' oftheAwasaWoreda, Sidama Zone, Southern Ethiopia. MSc. Thesis. pp 99.

[62] Zinash W. (2015). Assessment of livestock production practices and feed resources in peri urban and rural areas of Sekota district in Waghimra zone, Ethiopia.

[63] Zinash, S., Aschalew, T., Alemu, Y. and T. Azage (2001). Status of Livestock Research and Development in the highlands of Ethiopia. In: Proceedings of the Two Stakeholder Workshops. Improving the Productivity of Crop-Livestock Production in Wheat Based Farming Systems in Ethiopia, Addis Ababa, Ethiopia. pp. 227-25. 